\title{
Valuation of native fruits and postcolonial thinking: a search for alternatives to development
}

\author{
Valorização das frutas nativas e pensamento pós-colonial: \\ busca de alternativas ao desenvolvimento
}

\author{
Rodrigo Ozelame da Silva ${ }^{a}$ \\ Julian Perez-Cassarino ${ }^{b}$ \\ José Edmilson de Souza-Limac \\ Walter Steenbock ${ }^{d}$
}

${ }^{a}$ Doutorando em Meio Ambiente e Desenvolvimento, PPGMADE-UFPR, Laranjeiras do Sul, PR, Brasil. E-mail: rodrigoozelame@gmail.com

${ }^{b}$ Doutor em Meio Ambiente e Desenvolvimento, PPGMADE-UFPR, Laranjeiras do Sul, PR, Brasil. E-mail: julian.cassarino@uffs.edu.br

'Professor do Mestrado em Direito, Unicuritiba, Curitiba, PR, Brasil. E-mail: jose.edmilson@pq.cnpq.br;

${ }^{d}$ Analista ambiental do Instituto Chico Mendes de Conservação da Biodiversidade (ICMBio), Doutor em Recursos Genéticos Vegetais, PRGV-UFSC, Itajaí, SC, Brasil.

E-mail:walter.steenbock@icmbio.gov.br.

doi:10.18472/SustDeb.v10n2.2019.22029

Received: 16/01/2019

Accepted: 19/08/2019

ARTICLE - VARIA

\begin{abstract}
This research aims to identify the influence of two paradigms, namely colonial thinking and postcolonial thinking, on the valuation of native fruits, The sample was composed of six groups of farmers from the agroecology center Luta Camponesa Nucleus, which is linked to the agroecology network Rede Ecovida de Agroecologia, and the methodological procedures were based on the principles of action research. It concludes that the colonial thinking contributes to the elimination of native fruits, as a result of epistemicide, the advancement of the green revolution, and the food empires. On the other hand, the postcolonial thinking valorizes native fruits, especially through the ecology of knowledges, agroecology, and short circuits.
\end{abstract}

Keywords: Sociobiodiversity; Agroecology; Ecology of Knowledges; Action Research.

\section{RESUMO}

A pesquisa tem como objetivo identificar a influência de dois paradigmas na valorização das frutas nativas, o pensamento colonial e o pensamento pós-colonial. O público foi composto por seis grupos de agricultores do Núcleo Luta Camponesa da Rede Ecovida de Agroecologia, enquanto os procedimentos metodológicos levaram em conta os princípios da pesquisa-ação. Como resultado, destaca-se a influência do pensamento colonial na desvalorização e até na eliminação das frutas nativas, resultado dos denominados epistemicídios, por meio, entre outros, do avanço da revolução verde e dos impérios 
alimentares. Por outro lado, o avanço de um pensamento pós-colonial coopera para a valorização das frutas nativas, sobretudo via ecologia de saberes, da agroecologia e dos circuitos de proximidade.

Palavras-chave: Agroecologia; Sociobiodiversidade; Ecologia de Saberes; Pesquisa-Ação.

\section{INTRODUCTION}

Brazil is the mega diverse country with the largest biodiversity in the world. Megadiverse countries include seventeen nations that account for $80 \%$ of the planet's biodiversity. This richness is the result of a millenary process involving factors such as sunlight incidence, rainfall, soil formation, nutrient cycling, and relationship between fauna and flora. Another factor was the actions performed by women and men, as they have contributed to the promotion of biological and cultural diversity throughout the history of the humankind especially through the domestication of plants, animals and landscapes (CLEMENT, 2001).

However, this process has been compromised, especially because of the advancement of a development model based on colonial thinking, which aims to implement in the world a single manner of producing, trading, validating knowledge and relating to nature. Among the native fruit tree species of the Atlantic Forest biome and their traditional and potential uses, which we chose to call native fruits in this research, these impacts are severe. This is because they, as well as their process of domestication, are invisible to the eyes of those who foster such a development model. However, this world-system is not the only way to exist. Other worlds are not only possible and necessary; they do exist. They are essentially diverse, but they unite under another form of globalization, namely the counter-hegemonic globalization (SANTOS, 2010).

This research emerges in this scenario. Its justification is underpinned by the search for alternatives for the valuation of native fruits, and its objective is to analyze the contributions and limits of the colonial and postcolonial paradigms regarding the valuation of these species. The sample consisted of six groups of farmers from the Luta Camponesa Nucleus of the Rede Ecovida de Agroecologia network, and the methodological procedures were based on action research principles (THIOLLENT, 2011).

It is worth mentioning that this work is related to several actions of valuation of native fruits, which have been carried out since 2014 by the Jorge Vivan Laboratory of Agroforestry Systems of the Federal University of Southern Frontier (UFFS), the Luta Camponesa Nucleus and the Center for Sustainable Development and Training in Agroecology (CEAGRO).

\section{METHODOLOGICAL PROCEDURES}

The method used in this research relies on the principles of action research. Action research can be defined as a qualitative research method. Thiollent (2011) argues that

Action research is a type of empirically based social research that is conceived and carried out in close association with an action or with the resolution of a collective problem in which researchers and participants representing the situation or problem are involved in a cooperative or participatory way (THIOLLENT, 2011, p. 20).

In an action research, instead of separation between subject and object, there is an interaction between two types of characters: the authors of the research (AUT) with the social actors (AU). The AUTs are responsible for the research, whereas the AU are linked to the action. However, a cooperative environment where occasionally the author becomes co-actor of the action and the actor becomes coauthor of the research may emerge. (THIOLLENT, 2011).

To materialize the link between authors and actors with native fruits, direct observation was used as a research tool. In short, direct observation means the monitoring of a group of people during certain activities. This monitoring may have a greater or lesser degree of participation, according to the objectives of the research and the reality of the social group (DEMO, 2004). 
Direct observation of six groups of farmers of the Luta Camponesa Nucleus was carried out, as described in the next section. This tool was used during eighteen group meetings (three with each group) discussing plant domestication, which are described in Silva (2018). In addition, there were fourteen visits to agroecological products fairs in the municipalities of Laranjeiras do Sul, Palmital, and Nova Laranjeiras, monitoring of two juice stalls at events in Laranjeiras do Sul, and two workshops on processing of native fruits held at the Laranjeiras do Sul campus of the Federal University of Southern Frontier.

\subsection{THE SOCIAL ACTORS AND THEIR CONTEXT}

The social actors of this research are farmers belonging to agroecology groups at the Luta Camponesa Nucleus. The center is linked to the Rede Ecovida de Agroecologia network, which is an organization made up of 4,500 families, about 200 green fairs and 27 centers, located in 352 municipalities in the states of Paraná, Santa Catarina and Rio Grande do Sul. The network operates in a horizontal and participatory manner and focuses on the promotion of agroecology (REDE ECOVIDA, 2019).

The Luta Camponesa Nucleus is located in the mesoregion of South-Central of the State of Paraná. This area had a late colonization process compared to the coast area. In the 20th century the colonization has been intensified, mainly through the establishment of logging companies and European migrants. In the 1970s, araucaria (Araucaria angustifolia), the main raw material for timber, became scarcer, so the planting of pine (Pinus elliotti) and eucalyptus (Eucalyptus spp), as well as extensive cattle farming, began. This process contributes to the intensification of agrarian conflicts and the emergence of temporary camps linked to the Landless Workers Movement, the MST. (SANTOS, 2016).

The last decade of the 20th century is marked by the creation of agrarian reform settlements, which are gradually introduced in the agriculture model of the green revolution, consolidating this model as the most commonly found in the region. In the 2000s, on the one hand the green revolution was consolidated, but on the other hand, the local social movements, especially the MST and the MPA (Small Farmers Movement), incorporated in their discourses the search for sustainable means of production, such as agroecology. This fact was crucial for the emergence of the Luta Camponesa Nucleus (SANTOS, 2016).

The center was founded in 2012 and its members include 220 settled families, temporary campers, and family farmers. Out of these, 53 families and six agribusiness companies are certified as agroecological, totaling an area of 550 certified hectares in two areas under the government's Territories of Citizenship program in the State of Paraná: Cantuquiriguaçu and Paraná Centro (SANTOS, 2016). The center is located in the Atlantic Forest biome, a forest biome with heterogeneous phytophysiognomy composed of a set of three forest formations (Ombrophilous Dense Forest, Ombrophilous Mixed Forest, and Seasonal Semideciduous Forest) and related ecosystems such as sand banks, mangroves, and highaltitude fields. In the land of the Luta Camponesa Nucleus, vegetation is mostly Ombrophilous Mixed Forest, or araucaria forest, and a Seasonal Semideciduous Forest ecotone (CANOSA, 2016).

Given this broad scenario, six groups of the center were selected according to the following aspects: i) the group's history regarding native fruits and ii) the group's desire to research this topic. Figure 1 shows the municipalities and the vegetation classification of the location where the groups are based, and Table 1 shows information about the selected groups. 

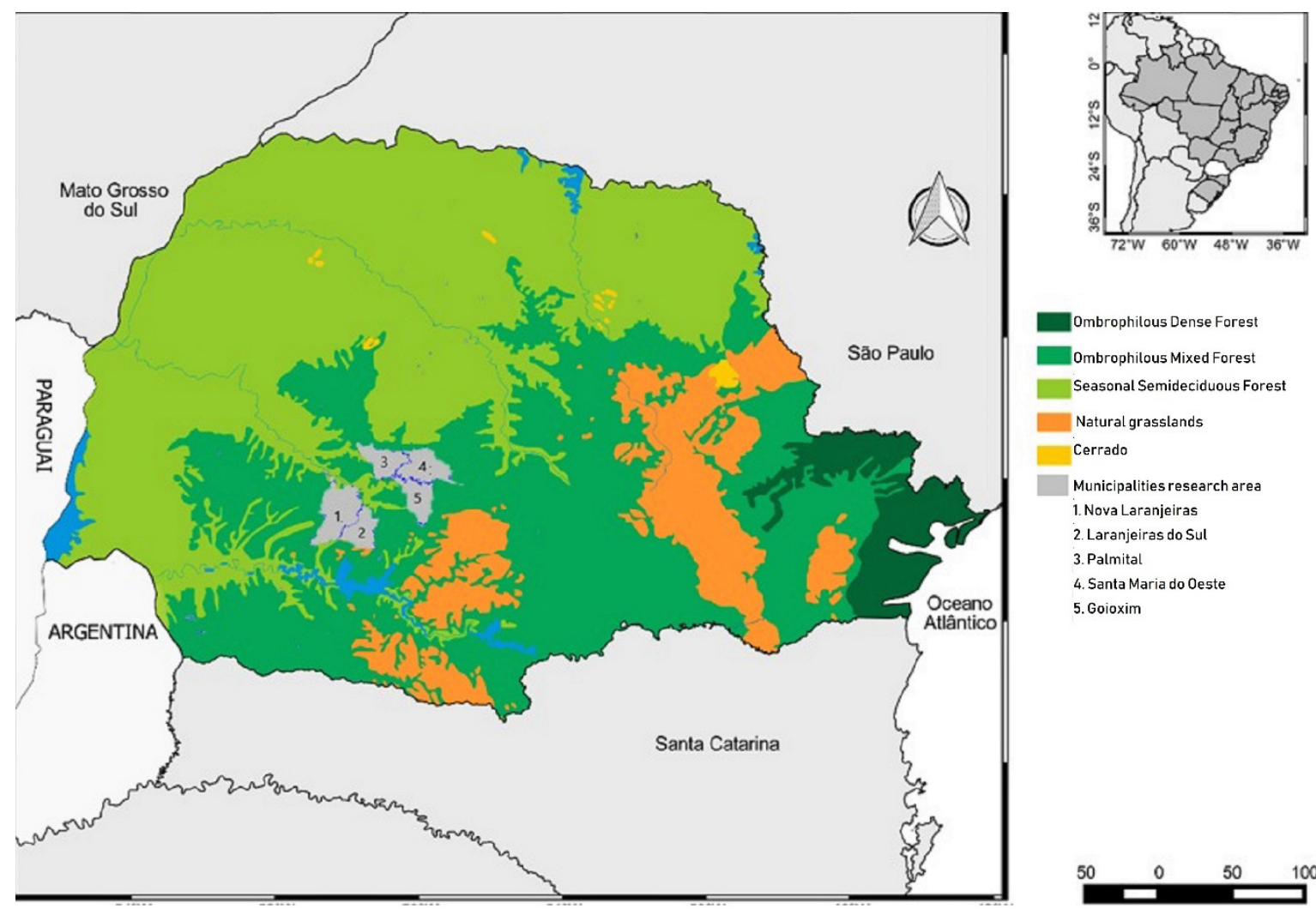

Ombrophilous Dense Forest

Ombrophilous Mixed Forest

Seasonal Semideciduous Forest

Natural grasslands

Cerrado

Municipalities research area

1. Nova Laranjeiras

2. Laranjeiras do Sul

3. Palmital

4. Santa Maria do Oeste

5. Goioxim

Figure 1 | Map of municipalities and forest classification of the groups of this research.

Source: IPARDES 2014, adapted by the researchers.

Table 1 | Research groups, municipalities, territories and movements the groups belonging to.

\begin{tabular}{|l|c|c|c|c|}
\hline$N$ & Group Name & Municipality & Territory of Citizenship & Rural Social Movement \\
\hline 1 & 8 de Junho & Laranjeiras do sul & Cantuquiriguaçu & MST \\
\hline 2 & Jabuticabal & Goioxim & Cantuquiriguaçu & MST \\
\hline 3 & Palmeirinha & Palmital & Paraná Centro & MST \\
\hline 4 & Recanto da Natureza & Laranjeiras do Sul & Cantuquiriguaçu & MPA \\
\hline 5 & Terra de Todos & $\begin{array}{c}\text { Palmital e Santa Maria do } \\
\text { Oeste }\end{array}$ & Paraná Centro & MST \\
\hline 6 & Terra Livre & Nova Laranjeiras & Cantuquiriguaçu & MPA \\
\hline
\end{tabular}

Source: Researchers, based on field research.

The groups are composed of 117 farmers in 33 families located in five municipalities, and all farmers are related either to the MST or MPA. 


\section{INFLUENCE OF COLONIAL THINKING ON THE INVISIBILITY OF NATIVE FRUITS}

Authors such as Santos (2002; 2009), Santos and Meneses (2010), Quijano (2010) and Dussel (1993) say that we live in a period marked by the colonial thinking. Such rationale began with the invasion of America, and is engendered by two abyssal lines (SANTOS, 2010). The first one is visible and separates the new from the old worlds (the colony from the metropolis); and the second one is invisible and separates social reality into two distinct worlds: the worlds on this side of the line, composed of civilized men, such as the European individual in the sixteenth century, and the world on the other side of the line where

there is no real knowledge; there are beliefs, opinions, witchcraft, idolatry, intuitive or subjective understanding, which can at best become objects or raw material for scientific inquiry. (SANTOS, 2010, p. 34).

These abyssal lines extend beyond what is legal or illegal, true or false. They separate the invisible from the visible, the state of nature from the civilized man, the underdeveloped from the developed. Whoever is on the other side of the line, including their knowledge and practices, are not right or wrong, for they do not exist. Therefore, modernity is constituted based on the invention of subhumanity (SANTOS, 2010).

Over the centuries, after the invasion, several features of colonial thinking have changed. The line separating colonies and metropolises no longer exists, but the invisible line separating humanity from sub-humanity remains as radical and exclusionary (SANTOS \& MENESES, 2010). Quijano (2010) says that the end of the domination relationship between colony and metropolis did not promote the freedom of those on the other side of the line; instead, the power structure has been maintained. This structure is explained by the concept of coloniality of power, as defined below.

\footnotetext{
Coloniality is one of the constitutive and specific elements of the world pattern of capitalist power. It has the imposition of a racial/ethnic classification of the world's population as the cornerstone of such pattern of power and operates in each of the material and subjective levels, means and dimensions of daily life and societal scale (QUINJANO, 2010, p.84).
}

Another change is the location of the dominant and dominated. Santos (2010) argues that today the abyssal lines separate the global South from the global North. The terms North and South are not geographical representations. Instead, they are cultural representations in which the "global South is conceived as the metaphor for systemic and unfair human suffering brought about by global capitalism and colonialism" (SANTOS 2010. p. 53). The global North is the institutionalization of the truth, the legal, the civilized men, that it, those on this side of the line (SANTOS, 2010).

Based on the global North, colonial thinking, which has always sought to occupy all spaces, was able to approach its goal in the late 20th century. This happened thanks to the progress of its technological bases (transportation, communication, advertising, production). Thus, hegemonic globalization emerges, meaning an ideological, material and technical system that aims to impose in the world a single way of existing, based on the canons of modern science and the capitalist system (SANTOS, 2010; QUIJANO, 2010).

The progress of such globalization has at its heart the dissemination of monocultures, which have the prefix "mono" because of the difficulty in dialoguing with other forms of existence and their ability to generate absences. Santos (2002) indicates the existence of five of them: i) monoculture of the criteria of capitalist productivity; ii) monoculture of linear time; iii) monoculture of the naturalization of differences; and v) the monoculture of knowledge and the knowledge of rigor. Monoculture of knowledge is the most intense form of producing absence, therefore we will see it in more depth in this research. It consists in transforming the epistemology of modern science as the sole source of truth. This led to the killing of various ways to validate knowledge, which is called epistemicide (SANTOS, 2010).

Monocultures contribute to make the dominant's ideas hegemonic in the globalization articulated by the colonial thinking. As a result, anything asymmetrical to that is essentially subordinate. This paradigm alters several aspects of reality, such as the relationship with native fruits, as explained below. 


\subsection{THE RURAL SPHERE "ON THIS SIDE OF THE LINE": EPISTEMICIDE, GREEN REVOLUTION, AND FOOD EMPIRES}

The colonial thinking encompasses various aspects of the rural sphere. However, three of them comprise the guiding principle of the influence of this thinking on native fruits: i) epistemicide (SANTOS, 2010); ii) the green revolution (GLIESSMAN, 2001), and the food empires (PLOEG, 2008).

Epistemicide on the other side of the line, as previously mentioned, has killed several ways human beings validate and build knowledge (SANTOS 2010; MENESES and NUNES, 2005). As a result, a wide range of knowledge and practices that human beings have developed with nature has been eliminated. This elimination contributes to driving the knowledge acquired by the Homo sapiens in the course of 200,000 years of history to extinction (TOLEDO \& BARRERA-BASSOLS, 2015).

Given this picture, we can put into perspective some situations regarding native fruits. According to reports from local farmers, some native fruits, especially gabiroba (Campomanesia xanthocarpa), are classified as pork food. If, on the one hand, this classification can be explained by the interaction between animals and plants, which is positive, on the other hand, it is pejorative. During interactions with the sample of this research, we recorded lines such as: "you grew up eating gabiroba and now you want to choose what to eat?", meaning that eating native fruits is synonymous with uncivilized. The following excerpt illustrates this situation.

You know this native fruit thing is something I've been enjoying thinking more about. Here we have a lot, but I would like you to see it at my grandma's house, she's sort of indigenous descendant, and she has many kinds of uvaia trees in her land, l'll bring some to plant this year. But sometimes, even among acquaintances, when we say that we will harvest, process or that we are selling native fruit, people laugh, gossip and mock. To many people, farming means kicking everyone out of the land, clearing the whole forest, planting one single thing, cover it with pesticides, and sell it to the intermediate buyer. But our project of society and life is peasant-like. And native fruits have everything to do with our project (Farmer 8).

We note there is a mixture of invisibility and disqualification of native fruits. Actions and stories related to native fruits, such as the grandmother who grew uvaia (Eugenia pyriformis), are rarely acknowledged. Even when acknowledged, they are considered retrogression, and their elimination is necessary for an agricultural model that removes women, men and the forest. Farmer 3 points out a passage in his life that exemplifies this invisibility.

Since the time we were camped, 30 years ago, I've played some leadership role. And I was always against cutting off trees, especially on the banks of rivers, and fruit trees. Because besides protecting the water, they provide food for us, for production and for animals. I would even get into argument but wouldn't let them do it. This idea of protecting trees and river banks started to spread. I'll tell you a story, one day we went to the bank. There the parish priest of the settlement came talk to me and said, "You need to move to town. I'll talk to the mayor to get you some regular delivery of staples. Because this thing that you do there, leaving bushes grow everywhere, is not agriculture. Look, I know Europe, real agriculture, it has to be organized, with machinery and a lot of production." I said "ok, father," then I left... (Farmer 3)

Although the priest's opinion is not the Catholic Church's view, it reveals the dominant idea that trees are a hurdle. This elimination does not apply to native fruits only, it also includes the entire forest area. For example, in Paraná, the state this research was carried out, the forest area in 1890 occupied $83.41 \%$ of the total area of the state. In 1990 , this number was reduced to $5.2 \%$, which is a loss of $78.21 \%$ of vegetation cover in approximately 100 years (GUBERT, 2010). Along with the forest landscape, the wildlife and the relationship of coexistence between women and men and the nature are severely damaged.

As Celso Furtado (2007) points out, a model of intensive, expansionist, cyclical agriculture based on commodity production for the foreign market is implemented where there were forests before. Over time, wood, sugarcane, coffee and soybeans are examples of commodities produced. However, with the emergence of the green revolution, changes have been intensified. The green revolution is an agricultural model based on large-scale farms. Its premise is that the environment must adapt to the plant, so nitrogen fertilizers, pesticides and genetically modified seeds are used. These items work interdependently and form the green revolution package (GLIESSMAN 2001). 
This package makes the rural space a subaltern place, especially for those on the other side of the line. Farmer 9 shares his group's experience using with this model.

When there were camps here, collectively, we used to grow corn and beans using fertilizer, pesticides and machinery. Not only to eat, but to sell. At that time, if we found any forest we would soon think of clearing and growing corn and beans. In some weeks, two or three trucks loaded with pesticides, compost, and seeds would come. But by growing like this, we were almost associated with the agriculture retailer, and the bills began to accumulate. In the end, our earnings matched our costs, and we didn't even add the cost of the working time of families. I am not ashamed to tell this, because I have learned the importance of contradiction. Today, almost every group uses agroecology. In my lot, only there are more than a thousand trees planted, besides the areas of low vegetation (capoeiras) that is growing (Farmer 9).

Supporters of this agricultural package argue that it colonizes the planet by aiming to end hunger. But its impacts also spread across the globe. This agriculture model is the human activity with the greatest environmental impact on the planet today. It is primarily responsible for water consumption, greenhouse gases and deforestation (FAO 2006). This model also makes most of the rural inhabitants move to the big cities. In Brazil this process is emblematic. In 60 years (from 1950 to 2010), the rural population decreased from $69 \%$ to $16 \%$ (IBGE, 2010). This migration flow substantially changes the characteristics of Brazil, such as the formation of a population of proletariat whose eating habits are different from the rural inhabitants', for instead of producing their food, they purchase it in supermarket chains.

This change in consumption contributes to the emergence of another aspect, namely, the food empires. Empires materialize into oligopolies of transnational corporations operating in the production, processing and distribution of food. These chains exert economic and political control, strong influence on the regulation of these activities, and they fiercely attack any type of alternative that contradicts their interests, thus constituting an invisible network with enormous coercive power (PLOEG, 2008).

This process contributed to the homogenization of production and consumption, resulting in the loss of local food cultures and, therefore, of food products and traditional knowledge related to them. As food empires become global, homogeneity in food consumption increases. This forms a cyclical and expansionary movement for the elimination of socio-biodiversity, which is illustrated in the following passage.

\begin{abstract}
We tried to sell bread to a supermarket chain. Because it was organic, the market got interested and we started a conversation. We took some samples of cassava bread, pumpkin bread, and sweet potato bread. We thought the beautiful colors of the bread and the different flavor would appeal, but it actually became an issue. The store owner said: "I'm interested in organic bread, but if it's mixed with other things and with this different color it's not nice. If you have white bread like the one we sell here, we can talk again." I tried to explain that our bread was more nutritious, beautiful, that we do not produce wheat and we exchange almost half of the wheat for products that we produce, but it was useless (Farmer 8).
\end{abstract}

This homogenization movement directly impacts the consumption, processing and marketing of native fruits. According to FAO (2005), there are over 300,000 plant species described, out of which 30,000 have been reportedly used as food. However, currently only 12 plants are responsible for $75 \%$ of the planet's plant food. "Three of them - rice, corn and wheat - account for $60 \%$ of the protein calories obtained from plants by humans" (FAO, 2005, p. 5). The report of a consumer at a native fruit juice stall at an event in Laranjeiras do Sul PR contributes to this discussion:

\footnotetext{
I've worked as an agronomist for the Government of Paraná for 10 years ago, and I've never tried this flavor of juice. I participate in a lot of events in the state, and normally, when there is fruit juice it is orange, strawberry, pineapple, these more commonly used fruits. But native fruit is new. Too bad it will be hard to find. I've never seen it available for purchase and I think I will not find such juice in supermarkets in Curitiba (Consumer 1).
}

Although a discussion about supply and consumption is not the focus of this research, it is worth noting that a professional with experience in agricultural technical assistance had not had access to the consumption of native fruits. This difficulty indicates limits in the insertion of these products in large supermarket chains that comprise the food empires.

In summary, colonial thinking in the rural sphere disregards and seeks to eliminate ways of relating to nature other than those based on the prescription of the green revolution and structured under the auspices of food empires. In this scenario, native fruits are excluded and invisible to colonial thinking. 
The result of this process is the compromise of the millenary relationship of co-existence between women and men with the nature, and especially native fruits.

However, the path indicated by colonial thinking is not the only path. In the next section, we will present alternative possibilities within this world-system, the so-called postcolonial thinking.

\section{INFLUENCE OF POSTCOLONIAL THINKING ON THE VALUATION OF NATIVE FRUITS}

This section focuses on explaining the emergence of paths that go beyond colonial thinking, especially regarding the valuation of native fruits. These alternatives will be grouped under the term postcolonial thinking. The basic premise is that this thinking has its origin in the subjects that are on the other side of the line (SANTOS, 2010).

But what is on the other side of the line? On the other side of the line there is a range of world-systems marked by heterogeneity. This diversity cannot be described in this research. Examples of it are the hundreds of ethnic groups that resist, from the Land of Fire to Alaska, or women, rubber tappers, peasants, quilombolas, land reform settlers, and family farmers struggling for (social) environmental justice (DUSSEL, 1993). That is, the other side of the line consists of a number of stories, relationships, knowledge, practices, ways of validating knowledge, and different and divergent ways of coexisting with the nature from the ways of the hegemonically established model. After all, as Toledo and Barreto (2015) point out, for Homo sapiens to stay alive for 200,000 years, it was necessary to diversify: plants, landscapes, practices, and knowledge.

Within this heterogeneity, some common aspects unite such subjects, such as being colonized and being together in the sub-humanity created by colonial thinking (SANTOS, 2010). To maintain diversity and generate rapprochement and changes in the reality, postcolonial thinking seeks to put a check on each of the monocultures of colonial thinking, and replace them with ecologies, which are based on the "recognition of the plurality of heterogeneous knowledge and sustainable and dynamic interactions among them without compromising their autonomy" (SANTOS, 2010, p. 53).

Santos (2002) indicates the existence of five ecologies: i) ecology of temporalities; ii) ecology of recognition; ii) ecology of trans-scale; iv) ecology of productivity and; v) ecology of knowledges. This ecology is a response to the monoculture of knowledge and the knowledge rigor, which is the most intense form of producing absence, therefore it will be detailed in this text. The ecology of knowledges aims to articulate dialogues between the different knowledges of the subjects on the other side of the line, so that the cognitive process of others is respected and the knowledge of all is broadened, increasing the possibilities of modifying the reality.

Based on the need to search for dynamic balances through these ecologies, recognition of the influence of colonial thinking, and valuation of diversity, some subjects on the other side of the line started a movement toward unity. This unity occurs through the constitution of networks: first locally, then globally. These networks aim to resist colonial thinking, to argue (and to practice) that other worlds are not only necessary; they already exist. This process is called counter-hegemonic globalization (SANTOS, 2010).

This manner of constructing knowledge is based on two sociologies: absences and emergencies. The sociology of absences aims to reverse the waste of human beings' experiences and knowledges. Its strategy is to liberate experiences and their actors from the relations of domination and unfeasibility, making them present, that is, making them visible. The sociology of emergencies aims to reduce the void caused by the definition that the Eurocentric/Western path is the only one. It questions the premise that time is linear and that history has only one direction, from underdevelopment to development. This sociology seeks to replace the ready-made future, the European one, with an uncertain and plural future, full of directions and possibilities that emerge in practical experiences articulated by the subjects on the other side of the line (SANTOS, 2002). 
Based on the presentation of these concepts, which are key for postcolonial thinking, the next section will be an exercise to relate this paradigm with the rural sphere, especially with native fruits.

\title{
4.1 THE RURAL SPHERE "ON THE OTHER SIDE OF THE LINE": ECOLOGY OF KNOWLEDGES, AGROECOLOGY AND SHORT CIRCUITS
}

In this section we will address three aspects through which postcolonial thinking impacts the rural sphere: i) construction of knowledge via the ecology of knowledges (SANTOS, 2010); ii) emergence of agroecology (GLIESSMAN, 2001) and; iii) possibility of solidary trading relations through short circuits (PEREZ-CASSARINO, 2012).

Postcolonial thinking replaces the logic of epistemicide with the rescue and valuation of knowledge by broadening what is considered valid knowledge through the sociologies of absences and emergencies and by articulating this richness via the ecology of knowledges (SANTOS, 2010). As a result, the historical process that each community has built with nature over time is now analyzed as a possible path. From this acknowledgement, there is a sum of experiences from other contexts of the networks that compose the counter-hegemonic globalization.

In this melting pot in which knowledges merge and amalgamate, the logic that knowledge is developed in research spaces and transferred to farmers is questioned. Instead, the search for the creation of environments where everyone can ask/answer and teach/learn emerges, because the premise that "teaching is not to transfer knowledge, but to create the possibilities for its production or construction" (FREIRE, 1996, p. 21) is acknowledged as valid. In this teaching and learning environment, the amount of possible management, agricultural techniques and use of plants is broadened, that is, the biocultural memory of the human species is diversified (TOLEDO and BARRERA-BASSOLS 2015).

In the context of native fruits, the ecology of knowledges demystifies the pejorative way that part of our society regards such species and values the process of their domestication. Thus, an important step, perhaps the first, is to rescue and promote new viewpoints on native fruits, as noted in the following passage.

\begin{abstract}
After I saw the processing of native fruits, the products you can do and their marketing, I began to pay more attention to them. I was talking at home these days about the number of things we have that never paid attention to. There are times when the ground turns yellow with some many gabirobas and I never imagined I could use the fruit to do so many things and never thought about the income they could bring. Now I'm paying more attention and started the pruning; I already did it to the pitanga trees and strawberry guava trees, which are kind of small. I also want to open around those trees that are too stifled (Farmer 12).
\end{abstract}

When farmer 12 reports having had access to other experiences, by interacting with other farmers, technicians and researchers, the knowledge, practices and the motivation to work with native fruits increase. Observing and managing these species is a fundamental part of rescuing the native fruit domestication process (CLEMENT, 2001).

Another aspect of postcolonial thinking that modifies the rural sphere is the emergence of agroecology. We consider it as part of postcolonial thinking due to the following aspects: i) valuation of the knowledge of subjects on the other side of the line, such as the indigenous people of Latin America (ALTIERI, 2009); ii) its complex approach, which seeks to analyze social, environmental and economic aspects of reality, producing interdependent and dynamic changes in it (SEVILLA-GUZMÁN, 2002); iii) valuation of the diversity of knowledges and the dialogue between them (LEFF, 2002); iv) the intention to build and manage sustainable agroecosystems, strengthening essential ecological processes through interactions with the human management of them (ALTIERI, 2009).

In this context where agroecology, postcolonial thinking and valuation of native fruits come closer, Gliessman (2001) argues that the technical and productive dimension of agroecology has its peak when it generates complex production systems that mimic the functioning of the original ecosystem. As the original physiognomy of the ecosystems analyzed in this research is forest, the path to sustainability involves the incorporation of trees in the spaces of production. In this incorporation, 
adding locally-adapted individuals, such as native fruit populations, tends to promote the sustainability of agroecosystems. Report of farmer 13 problematizes such relationship.

Look, all this area here used to be bush. And not that long ago. In my father's time it was all low vegetation areas. In 40 years say we cut off all the trees and introduced the pesticides. Nowadays, it is rare to grow a crop that doesn't have an issue. It's ants, crickets, diseases and so on. But when we look at the forests, is there any disease? Sure there are some things, but the amount of good things is much bigger. This is why this agroforestry work is important, for us to have a balanced production. And why not to add native fruits too? They have been there for a long time, they are used to our environment (Farmer 13).

Another aspect that relates native fruits to agroecology is the dialogue of knowledge. It enables the participatory construction of the social and environmental features that farmers want to find in native fruit trees. This environment of dialogue allows for the opinions of farmer 14:

I have no doubt that the most important thing to choose a good gabiroba tree is the taste and smell of the fruit. What is the point of having a big fruit, but tasteless? It has to have that smell that we feel from afar and it has to be tasty. Otherwise it becomes just like those market foods that taste like nothing, it's just about size. Like the poultry and pork that seem to have air inside, or the corn that doesn't even smell like corn. I don't know about other people, but to me real food has to smell and taste like real food (Farmer 14).

When views are shared and brought together through dialogue of knowledge (LEFF, 2002), the multidimensionality of the rural sphere (and native fruits) becomes more evident, as observed in the choice of indicators for good trees in the speech above. It leads to the creation of teaching-learning environments that tend to act in agroecosystems and native fruits in a more complex way.

Given that postcolonial thinking relates to agroecology, it interacts with the rural sphere by questioning the fact that food empires are the only way to deal with consumers. Thus, the myth that there are no alternatives to capitalism is questioned through the analysis of non-capitalist production paths, where one seeks to produce for a living and not for accumulating. This search for more equality in the trading relations has aroused discussions by various rural actors. An example of this process is short circuits. These short circuits guide new possibilities among the subjects in food systems aiming to build relationships and spaces of exchange where physical closeness enables sociability between producers and consumers, such as the social construction of the value of products, the food standard, and its uses. (PEREZ-CASSARINO, 2012).

With regards to native fruits trading, it was identified that the short circuits leverage the marketing of these species, especially in agroecological products fairs, as described by farmer 16 during the fair that her group organizes in Laranjeiras do Sul PR.

This year we made almost 500 reais by selling packs of pitanga and gabiroba at the fair. It doesn't seem to be much, but it helps. It is basically profit, as we spent almost nothing to earn it. And if we don't sell anything, we bring it back and eat or feed the animals. There is no loss. Another good thing is that when people come to the fair they rarely buy only one thing; they see a pack of pitanga on the stall and stop, then they see other things and end up getting them too (Farmer 16).

Short circuits also collaborate in communicating the social and environmental benefits of native fruits. For example, at fairs, farmers report the advantages of consuming native fruits and make some species available to be tried for the first time. A consumer at a native fruit juice stall expresses this process.

I've never had gabiroba juice before. I think it is very good. There are some many fruits out there and we do not value them. Sometimes we buy juice or soda in the supermarket and we do not realize what nature provides. Thank you! It made my day, I'll bring my dad later, he'll love it. My children never had the fruit either, they'll try it for the first time today! (Consumer 2).

Short circuits allow for consumers to value native fruits, and the feedback movement also exists. During a visit to a fair organized by the Terra Livre group in Nova Laranjeiras PR, the group's experience selling gabiroba was monitored. At this fair, a consumer talked to the group about how the fruit taste reminded her of her childhood. In the dialogue, the consumer asked what other native fruits the farmers had in their family farms. The result of this dialogue was the ordering of other fruit species, which motivated farmers to operate with a greater diversity of native fruits. 
The rapprochement and dialogue between farmers and consumers contribute to another aspect of the articulation between postcolonial thinking and the rural sphere, namely, the solidary access to native fruits. In other words, in addition to having the chance to buy native fruits, consumers can buy them at prices affordable to the majority of the population. Farmer 9's speech exemplifies this rationale.

\begin{abstract}
Our struggle is not to produce organics and sell to those who have the money to pay. Firstly, we struggle for land reform, so that everyone can produce their own healthy food, protecting nature, and native fruits have everything to do with our dream. But while we wait for that day, we collectively decided to sell products at a price that people who need it most can afford. That's why we started to hold a fair every week right in the middle of a poor neighborhood in Laranjeiras do Sul (Farmer 9).
\end{abstract}

Although farmer 9 does not explicitly says that solidarity-based trading concerns native fruits, it can be implicitly considered so, because the mentioned group sells native fruits at fairs, and the speech was extracted from a dialogue whose topic was native fruits.

Hence, when postcolonial thinking is based on an ecology of knowledges, it helps promote the diversity of knowledges and practices that involve men and women relations with each other and with nature. This wide range of possibilities fosters the creation of sustainable modes of production and trading, such as agroecology and short circuits. Part of this range of alternatives unite in the counter-hegemonic globalization to resist the advancement of colonial thinking and to advocate that other worlds are possible. In this context, socio-biodiversity, and especially native fruits, are valued by both producers and consumers.

\title{
5 FINAL CONSIDERATIONS
}

Valuing or eliminating native fruits is the result of a range of aspects with several dimensions that go beyond the scope of this research. Nevertheless, according to the aim of analyzing the relationship of these species under two paradigms, the colonial and the postcolonial, we can point out some tendencies. Although such tendencies need further research and actions, Table 2 shows the systematization of key concepts and their consequences in each paradigm analyzed.

Table 2 | Summary of tendencies and consequences of colonial and postcolonial paradigms' influence in the valuation of native fruits.

\begin{tabular}{|c|c|c|c|}
\hline \multicolumn{4}{|c|}{ VALUATION OF NATIVE FRUITS } \\
\hline \multicolumn{2}{|c|}{ COLONIAL THINKING } & \multicolumn{2}{|c|}{ POSTCOLONIAL THINKING } \\
\hline FOSTERS & TENDENCY & FOSTERS & TENDENCY \\
\hline Epistemicide & $\begin{array}{c}\text {-Elimination of relationships } \\
\text { between human beings and native } \\
\text { fruits }\end{array}$ & $\begin{array}{l}\text { Ecology of } \\
\text { Knowledges }\end{array}$ & $\begin{array}{l}\text {-Rescue and strengthening of } \\
\text { sustainable relationships with native } \\
\text { fruits }\end{array}$ \\
\hline Green Revolution & $\begin{array}{c}\text {-Homogenization of productive } \\
\text { systems } \\
\text {-Elimination of forest } \\
\text { agroecosystems }\end{array}$ & Agroecology & $\begin{array}{c}\text {-Building of complex agroecosystems } \\
\text {-Valuation of forest species adapted } \\
\text { to each context }\end{array}$ \\
\hline Food Empires & $\begin{array}{l}\text {-Homogenization of eating habits } \\
\text {-Difficulty in finding native fruits. }\end{array}$ & Short circuits & $\begin{array}{l}\text {-Information exchange about } \\
\text { native fruits consumption between } \\
\text { producers and consumers } \\
\text {-Easier logistics }\end{array}$ \\
\hline
\end{tabular}

Source: The researchers, based on field research. 
Although the tendencies pointed out cannot be analyzed linearly (cause and effect), as a table might suggest, one can observe three intertwined elements fostered by colonial thinking. The first one is the epistemicide of those on the other side of the line, which entails the elimination of co-existence relationships between human beings and nature, including the relationships with native fruits. An example of it is the pejorative way that part of our society regards any relationship with native fruits.

The second element is the advancement of the green revolution. This process contributes to the homogenization of production systems. As diverse agroecosystems and the presence of the trees evade the logic of the green revolution, such environments tend to be eliminated. Arguments against native fruits, such as the idea that trees hinder and makes agriculture difficult, illustrate this process. The food empires, which is the third aspect, operate by changing the eating habits, especially of subjects that migrate from rural to urban areas. Likewise, they control the productive chains and determine their logic of organization and functioning. This change leads to the replacement of food produced by families, such as native fruits, with a less diversified diet purchased from transnational retail chains.

Regarding the influence of post-colonial thinking on the valuation of native fruits, we also present three main aspects. The ecology of knowledges is the first one, and probably the main aspect, since it creates the epistemological basis for rescuing absences and understanding the emergencies of the diversity of historical relationships that women and men have with native fruits, thus expanding the theoretical and practical framework regarding the management and use of these species.

The rescue of the observation of native fruits and the exchange of knowledges and practices about them portray how the ecology of knowledges contributes to the valuation of these species. Agroecology, the second aspect, is a key element, as it seeks to build complex agroecosystems, which take into account the phytophysiognomy and biocultural memory of each location and provides for the maintenance and multiplication of existing native fruit trees in family farms. The third aspect, trading through short circuits, supports the construction of spaces to sell and disseminate native fruits, such as the fairs observed in this study, and strengthens a perspective of food as a human right, that is, making it affordable and culturally, environmentally and socially appropriate.

To conclude this research, it is worth pointing out that the rescue and promotion of native fruits will only be successful if the development model presented by colonial thinking changes. For such, it is not enough to look for alternatives within the current model; instead, alternatives have to be fostered. In other words, it is not enough to reform the development; it is necessary to build other forms of human beings' involvement with each other and with nature.

\section{REFERENCES}

ALTIERI, M. Agroecologia: a dinâmica produtiva da agricultura sustentável. Porto Alegre: UFRGS, 2009.

CANOSA, J. L. Proposta Metodológica para planejamento participativo de sistemas agroflorestais junto a agricultores(as) familiares. Dissertação de Mestrado, Programa de Pós-Graduação Agroecologia e Desenvolvimento Rural Sustentável, Universidade Federal da Fronteira Sul, 2016.

DEMO, P. Pesquisa Participante: Saber pensar e intervir juntos. Brasília/DF: Liber Livros, 2004.

DUSSEL, E. 1492, O encobrimento do outro (A origem do “mito da Modernidade”). Petropolis: Cortez, 1993.

FAO - Food and Agriculture Organization of the United Nations. "The State of World Fisheries and Aquaculture", Rome, Italy 2006.

FAO - Food and Agriculture Organization of the United Nations. Interação do gênero, da agrobiodiversidade e dos conhecimentos locais ao serviço da segurança alimentar. Manual de Formação. FAO, 2005.

FREIRE, Paulo. Pedagogia da Autonomia Saberes Necessários à Prática Educativa. 29 edição. São Paulo- SP: Ed. Paz e Terra, 1996. 
FURTADO, Celso. Formação econômica do Brasil. São Paulo: Companhia das Letras, 2007.

GLIESSMAN, S. R. Agroecologia: processos ecológicos em agricultura sustentável. Porto Alegre: Universidade Federal do Rio Grande do Sul - UFRGS. 2001

GUBERT, F.A.F. O Desflorestamento do Paraná em um Século. In: SONDA, C.; TRAUCZYNSKI, S.C. Reforma Agrária e Meio Ambiente: Teoria e Prática no Estado do Paraná (ORG). Curitiba: ITCG, 2010. p. 15-27.

GUZMÁN, E. S. A perspectiva sociológica em Agroecologia: uma sistematização de seus métodos e técnicas. Rev. Agroecologia e Desenv. Rur. Sustent. Porto Alegre, v.3, n.1, jan./mar.2002. p.18-28.

IBGE. Instituto Brasileiro de Geografia e Estatística. Censo demográfico 2010. Available at: <https://censo2010. ibge.gov.br/.> Access on: 7 Dec 2017.

LEFF, E. Agroecologia e saber ambiental. Rev. Agroecologia e Desenv. Rur. Sustent. Porto Alegre, v.3, n.1, jan./ mar.2002. p. 36-51.

PEREZ-CASSARINO, J. A construção social de mecanismos alternativos de mercado no âmbito da Rede Ecovida de Agroecologia. Tese de Doutorado, Programa de Pós-Graduação em Meio Ambiente e Desenvolvimento, Universidade Federal do Paraná, Curitiba, 2012.

PEREZ-CASSARINO, J; FERREIRA, A. D. D. Redesenhando os mercados: a proposta dos circuitos de proximidade. Revista Espacio Regional. Osorno, v. 1, n. 13, ene-jun/2016. p. 49-65.

PLOEG, J. D. V. Camponeses e impérios alimentares: lutas por autonomia e sustentabilidade na era da globalização. Porto Alegre: Editora da UFRGS, 2013.

QUIJANO, A. Colonialidade do poder e a classificação social. In: SANTOS, B. S.; MENESES, M. P. G. (Orgs.). Epistemologias do Sul. São Paulo: Cortez, 2010. p. 32-84.

REDE ECOVIDA. Como a Rede Funciona. Available at: <http://ecovida.org.br/sobre/ >. Access on: 14 Aug 2019.

SANTOS, B. S. Para uma Sociologia das Ausências e uma Sociologia das Emergências. Revista Crítica de Ciências Sociais Ciencias Sociais. Coimbra, Portugual, v. 63, p. 237-280, out., 2002.

SANTOS, B. S.; MENESES, M. P. G. (Orgs.) Epistemologias do Sul. São Paulo: Cortez, 2010.

SANTOS, B. De S.. Para além do pensamento abissal: das linhas globais a uma ecologia de saberes. In: SANTOS, B.de S.; MENESES, M. P. G. (Orgs.). Epistemologias do Sul. São Paulo: Cortez, 2010. p. 31-83.

SANTOS, B. S; MENESES, M. P. G.; NUNES, J. A. Para ampliar o cânone da ciência: a diversidade epistemológica do mundo. In SANTOS, B. DE S. (Org.). Semear Outras Soluçoes: os caminhos da biodiversiade e dos conhecimentos rivais. Rio de Janeiro: Civilizaçao Brasileira. 2005. p. 21-133.

SANTOS, C. R. L. Análise do processo de transição agroecológica das famílias agricultoras do Núcleo da Rede Ecovida de Agroecologia Luta Camponesa. Dissertação de Mestrado, Programa de Pós-Graduação Agroecologia e Desenvolvimento Rural Sustentável, Universidade Federal da Fronteira Sul, 2016.

SILVA, R.O.: Frutas Nativas, domesticação de plantas e Agroecologia: por uma outra relação com a sociobiodiversidade. Dissertação de Mestrado, Programa de Pós-Graduação Agroecologia e Desenvolvimento Rural Sustentável, Universidade Federal da Fronteira Sul, 2018.

THIOLLENT, M. Metodologia da pesquisa-ação. Rio de Janeiro: Cortez, 2011.

TOLEDO, V. M.; BARRERA-BASSOLS, N. A memória biocultural: a importância ecológica das sabedorias tradicionais. São Paulo: Expressão Popular, 2015. 